\author{
Ruhet Genç \\ https://orcid.org/0000-0002-8432-2714 \\ Turkish-German University (TGU) \\ Faculty of Economics \& Administrative Sciences \\ e-mail: drgench@gmail.com
}

\title{
EKONOMIA WSPÓŁDZIELENIA I ZARZĄDZANIE ZRÓWNOWAŻONYM ROZWOJEM ŚRODOWISKA W SEKTORZE TURYSTYCZNYM W SKALI GLOBALNEJ
}

\begin{abstract}
Abstrakt: W artykule zostanie omówiony wpływ rozwoju ekonomii współdzielenia na równowagę ekologiczną w sektorze turystycznym, w skali globalnej, jako że w literaturze jak dotąd nacisk jest kładziony głównie na konsekwencje ekonomiczne i społeczne. Zaprezentowano model matematyczny w celu oceny wpływu ekonomii współdzielenia na dobrobyt jednostek, które uczestniczą w działaniach z tego zakresu w konkretnych miejscowościach turystycznych. Autor opisuje też korzyść odnoszoną przez inne jednostki w postaci ich pozytywnego wizerunku zewnętrznego. Rozwój modelu będzie zależał od wyników przyszłych badań. Z pewnością wykażą one, że ekonomia współdzielenia wraz ze konsumpcją kolaboratywną w sektorze turystycznym stanowią rosnący trend w ekonomii światowej, który również przyczynia się do zrównoważonego rozwoju. Współdzieląc środki produkcji transportu, komunikacji itd., zarówno turyści, jak i usługodawcy są w stanie ograniczyć swój negatywny wpływ na środowisko. Artykuł wypełnia lukę w badaniach nad związkiem pomiędzy rozwojem zrównoważonym a ekonomią współdzielenia w sektorze turystycznym.
\end{abstract}

Słowa kluczowe: popyt sportowo-turystyczny, motywy i bariery, turystyka sportowa, międzynarodowe widowiska sportowe, kibice.

\section{WSTĘP}

Zastępowanie posiadania współdzieleniem stało się wiodącym trendem w ekonomii w skali globalnej. Ekonomia współdzielenia polega na partnerskim (peer-to-peer) pozyskiwaniu, udzielaniu - koordynowanego porzez system świadczonych społecznie usług - dostępu do dóbr i usług, lub dzieleniu się nim (Hamari, Sjöklint, Ukkonen, 2015). Ekonomia współdzielenia stała się atrakcyjną alternatywą dla konsumentów, coraz bardziej świadomych istnienia problematyki związanej ze środowiskiem naturalnym, jak np. zrównoważony rozwój, powiązania między zmianami klimatycznymi a nadmierną konsumpcją czy integracja społeczna poprzez lokalność oraz konsumpcję wspólnotową (Albinsson, Yasanthi Perera, 2012; Hamari, Sjöklint, Ukkonen, 2015). Wobec różnorodnych zachowań konsumenckich wspó1dzielenie staje się coraz istotniejszym tematem badawczym opisywanym w literaturze (Belk, 2010). W miejsce pojęcia „ekonomia współdzielenia” można zastosować termin „,konsumpcja współdzielona (kolaboratywna)”. Zdaniem Botsmana i Rogersa (2010) składa się ona zarówno z form współdzielenia, jak i wymiany. Oba te działania zwróciły uwagę badaczy, ponieważ wiele grup (przyjaciele, sąsiedzi, grupy obywatelskie, społeczno- ści uniwersyteckie itp.) organizuje wspólne wydarzenia w przeróżnych formach (Albinsson, Yasanthi Perera, 2012).

W wielu dziedzinach życia - od wspólnego użytkowania samochodu (ang. carpooling) do wspólnego mieszkania, a nawet żywienia się - ludzie zaczęli dzielić się $\mathrm{z}$ innymi tym, co mają, w zamian za to, czego potrzebują. Obok skutków ekonomicznych i społecznych głównym celem ekorozwoju jest korzyść płynąca ze współdzielenia aktywności. Dla przykładu - oszczędzanie energii, recykling, chodzenie pieszo zamiast jeżdżenia autem, jedzenie zdrowo oraz samodzielne wykonywanie przedmiotów można nazwać korzyściami ekonomii współdzielenia (Frick, Hauser, Gürtler, 2013; Schiel, 2015; Scholl, Schulz, Süssbauer, Otto, 2010). Współdzielenie prowadzi do zachowań politycznie poprawnych, które są wyrazem świadomego i inteligentnego (smart) miejskiego stylu życia (Schiel, 2015). Co więcej, zmniejszenie pojedynczych efektów wpływu na środowisko poprzez prowadzenie zdrowego trybu życia i unikanie zbędnych obciążeń środowiskowych jest również główną motywacją do stosowania ekonomii współdzielenia (van de Glind, 2013; Owyang, Samuel, Grenville, 2014). 
Dzięki współdzieleniu możliwe jest zmniejszenie negatywnego wpływu na środowisko, promowanie bardziej efektywnego korzystania z zasobów, jak również łatwiejsze nawiązywanie nowych kontaktów (Dubois, Schor, Carfagna, 2014; van de Glind, 2013; Schor, 2016).

W niniejszym artykule autor rozważa wpływ rozwoju ekonomii współdzielenia na stabilność ekologiczną w kontekście sektora turystycznego w skali globalnej. Powodem takiego podejścia jest fakt, że w literaturze przedmiotu główny nacisk jest kładziony na kwestię wpływów ekonomicznych i społecznych. W artykule zaprezentowano również możliwy matematyczny model do pomiaru wpływu ekonomii współdzielenia na dobrobyt jednostek (osób) uczestniczących w działaniach współdzielenia w poszczególnych destynacjach turystycznych, jak również przynoszących korzyści innym jednostkom (ludziom) jako efekt zewnętrzny. Rozwinięcie tego modelu będzie zależało od wyników uzyskanych w trakcie badań.

Wyniki badań pokazują, że ekonomia współdzielenia wraz z konsumpcją kolaboratywną w sektorze turystycznym stanowi wzrastający trend w gospodarce globalnej, który również przyczynia się do wzrostu ekorozwoju. Poprzez dzielenie środków produkcji, transportu, komunikacji itd. zarówno turyści, jak i usługodawcy są w stanie zredukować ślady, które pozostawiają w środowisku naturalnym.

Konkludując, niniejszy artykuł wzbogaca literaturę przedmiotu poprzez wypełnienie luki w badaniach nad związkiem między ekorozwojem a ekonomią współdzielenia w sektorze turystycznym.

\section{METODY}

W niniejszym artykule autor stosuje metodę przeglądu literatury, porównując ze sobą dotychczasowe badania nad turystyką, które dotyczyły różnych części świata.

\section{MORALNA EKONOMIA ORAZ TURYSTYKA ALTERNATYWNA}

Ekonomia współdzielenia stanowi wyzwanie dla modeli konsumpcji indywidualnej, której nadmiar grozi zaburzeniem równowagi ekologicznej, podczas gdy współdzielenie może znacząco przyczynić się do zmniejszenia obciążenie środowiska naturalnego, jak również poprawy ogólnego stanu zdrowia społeczeństwa (Albinsson, Yasanthi Perera, 2012). Wyzwanie to ma swój wymiar moralny, ponieważ wszelkiego rodzaju działania ekonomiczne ulegają wpływom oraz są kształtowane przez różne predyspozycje i normy moralne, które można albo pogodzić, albo pominąć lub wzmocnić poprzez presję społeczną (Sayer, 2004). W związku z tym w rozważaniach nad ludzkimi działaniami podejmowanymi w celu zapewnienia równowagi środowiska należy uwzględniać czynniki moralne obecne w filozofii I. Kanta.

Według Kanta imperatyw kategoryczny dotyczy poszukiwań oraz ustanowienia nadrzędnej zasady moralnej, która pełni funkcję uniwersalnego prawa natury (Kant, 1785). Innymi słowy, jeśli działanie jest właściwe - może zostać wdrożone, ale jeśli nie jest - podejmowanie go należy uznać za niewłaściwe (Rentmeester, 2010). W kontekście imperatywu kategorycznego Kanta oraz zmian klimatycznych stwierdzono, że działania proekologiczne mogą podlegać uniwersalizacji w ramach ogólnego i naturalnie samopodtrzymującego się modelu. Są one zatem prawidłowe/słuszne. Zachowania nieekologiczne nie mogą być zuniwersalizowane, tak więc są niewłaściwe (Schönfeld, 2008).

Gdy jednostki decydują się być odpowiedzialnymi konsumentami, którzy biorą sobie do serca kwestie ekorozwoju, angażują się we właściwe działanie. Co więcej, moralni konsumenci w sektorze turystycznym, tzn. moralni turyści, zazwyczaj częściej zastanawiają się nad wpływem, jaki wywierają na lokalne destynacje i gospodarki (Butcher, 2003), jak również postrzegają swoją własną mobilność, styl życia i wybory dotyczące konsumpcji jako sposób na samospełnienie przez zdobywanie doświadczenia oraz osiągnięcie sprawczości politycznej (Haenfler, Johnson, Jones, 2012). Dzięki alternatywnym formom turystyki, takim jak: ekoturystyka, turystyka typu slow czy turystyka wolontariatu, przed podróżnymi otwierają się lepsze możliwości zacieśnienia więzi ze światem niż w przypadku uległego hedonizmu, którego źródłem jest turystyka masowa (Fullagar, Markwell, Wilson, 2012; Lyons, Hanley, Wearing, Neil, 2012; Molz, 2013).

\section{EKOLOGICZNE PRAKTYKI WSPÓŁDZIELENIA W SEKTORZE TURYSTYCZNYM}

Nowe praktyki turystyczne pojawiły się w czasie, gdy w literaturze przedmiotu zaczęto rozważać moralne wartości turystyki masowej oraz moralne granice turystyki alternatywnej. Najnowszymi odmianami ekologicznej turystyki alternatywnej są turystyka typu slow, np. Cittaslow Movement (Fullagar, Markwell, Wilson, 2012; Pink, 2008), turystyka wolontariatu (voluntourism), która wzmacnia wartościowe doświadczenia i działania (Alexander, Bakir, 2010), oraz sieci wymiany gościnności (hospitality exchange networks), również te funkcjonujące w Internecie (Molz, 2013).

Równowaga ekologiczna jest jednym z głównych problemów dzisiejszego świata. Przedsiębiorstwa zwiększają swoje wysiłki na rzecz ekorozwoju, podczas gdy grupy konsumenckie poszukują ekologicznych rozwiązań 
potencjalnych problemów związanych z kryzysem energetycznym, degradacją środowiska, jak również globalnym krachem finansowym (Albinsson, Yasanthi Perera, 2012). Część tych ogólnoświatowych wysiłków powiodła się, w związku z czym można zaobserwować np.:

- rozwój polityki proekologicznej,

- instytucjonalizację biurokracji środowiskowej,

- stopniowe upowszechnianie się zarządzania proekologicznego w sektorze prywatnym,

- wzrastającą świadomość ekologiczną obywateli,

- wzrost aktywności społeczeństwa obywatelskiego reprezentowanego przez organizacje pozarządowe,

- rozwój interdyscyplinarnych nauk o środowisku i edukacji proekologicznej (Heinrichs, 2013; Jänicke, Kunig, Stitzel, 1999; McNeill, 2003).

Pomimo wielu już stwierdzonych działań proekologicznych na świecie, problemy ekorozwoju nie zostały całkowicie rozwiązane.

Konsumpcja kolaboratywna jest jedną z praktycznych możliwości, która ma na celu zmniejszenie negatywnego/ szkodliwego wpływu na środowisko naturalne poprzez antykonsumpcje oraz działania zorientowane na ekorozwój, takie jak odrzucenie lub zmniejszenie konsumpcji i ponowne używanie dostępnych produktów. Wysiłki te motywowane są indywidualnymi potrzebami i wartościami nowo kształtującej się grupy konsumenckiej, dla której ważny jest dobrostan środowiska (Black, Cherrier, 2010).

Ogólnie rzecz biorąc, odkąd globalny system gospodarczy współczesnego świata opiera się na zyskach oraz prywatnej własności środków produkcji, w społeczeństwach kapitalistycznych współdzielenie jest zaniedbywane i niedoceniane. System własności prywatnej stworzył swoją filozofię życia, znaną jako indywidualizm, który promuje wśród osób żyjących w społeczności skupienie się na sobie pomimo wspólnych interesów. Jednakże współdzielenie wydarzeń sprzyja zachowaniom proekologicznym oraz zwiększa korzyści odnoszone na różnych płaszczyznach przez całą społeczność, takie jak mniejszy wpływ klientów na środowisko oraz ich dobre samopoczucie psychiczne (Albinsson, Yasanthi Perera, 2012). W dalszej części artykułu zostanie przedstawiony model prezentujący możliwą relację matematyczną między omówionymi dwiema zmiennymi, tj. wpływem moralnej turystyki i ekorozwoju.

\section{MODEL}

Istnieją cztery czynniki, które można uwzględnić przy pomiarze wpływu ekonomii współdzielenia. Przede wszystkim dochody z turystyki odzwierciedlają poprawę dobrobytu mieszkańców danej miejscowości, wynikająca z mechanizmów ekonomii współdzielenia. Działania w turystyce alternatywnej, oparte na zasadzie współ- dzielenia, mogą zwiększyć komfort finansowy uczestników, którzy angażują się w tego typu interakcję, dzieląc się z innymi tym, czego potrzebuja, jednocześnie oszczędzając pieniądze. Wynika z tego, że korzyść ekonomiczna jest ważnym czynnikiem działań proekologicznych w ekonomii współdzielenia, a dochody uzyskiwane przez interesariuszy, równo rozdzielane pomiędzy usługodawców, mogą być uważane za wskaźnik wpływu konsumpcji kolaboratywnej.

Ponadto zmiany w ogólnej jakości życia turystów i usługodawców mogą stać się również wskaźnikiem wpływu ekonomii współdzielenia. Działania w ramach tej ekonomii w turystyce pozytywnie wpływają na dobre samopoczucie jednostek, które angażują się w aktywność turystyczną albo jako usługobiorcy, albo jako usługodawcy.

Oprócz wymienionych aspektów $\mathrm{w}$ modelu pomiaru wpływu ekonomii współdzielenia możemy uwzględnić regenerację środowiska jako wynik konsumpcji kolaboratywnej. $\mathrm{O}$ ile odpowiedzialni konsumenci będą stosować alternatywne sposoby konsumpcji, takie jak współdzielenie lub wymiana, w zamian za bezpośrednie posiadanie, degradacja środowiska naturalnego zostanie powstrzymana, a natura sama znajdzie sposób, by się odrodzić.

Wreszcie - możemy uwzględnić dodatkową przyjemność odczuwaną przez odpowiedzialnych konsumentów po zrobieniu tego, co uważają za swoją powinność. Dla nich ochrona środowiska jest jednym $\mathrm{z}$ głównych celów, więc jeśli ekonomia współdzielenia pomoże im przyczynić się do dobrostanu środowiska, będą czerpać przyjemność $\mathrm{z}$ wykonania swego nadrzędnego zadania.

Wspomniany model można przedstawić w następujący sposób:

$$
\mathrm{SE}=\beta_{0}+\beta_{1} \cdot \mathrm{TR}+\beta_{2} \cdot \mathrm{QL}+\mathrm{ER}^{\mathrm{t}}+d+\varepsilon,
$$

gdzie:

SE - wpływ ekonomii współdzielenia (sharing economy),

TR - dochody z turystyki (tourism revenues),

QL - jakość życia turystów i usługodawców (quality of life),

ER - regeneracja środowiska za sprawą ekonomii współdzielenia (environmental regeneration),

$t$ - czas,

$d$ - przyjemność czerpana ze spełnienia obowiązku wobec środowiska,

$\beta_{0}, \beta_{1}$ i $\beta_{2}-$ współczynniki,

$\varepsilon$ - reszta (tj. efekt innych zmiennych).

Konkludując, można stwierdzić, że wpływ współdzielenia jest zależny od czterech zmiennych, tj. dochodów z turystyki, jakości życia turystów i usługodawców, regeneracji środowiska oraz moralnego obowiązku związanego z ochroną środowiska. Mogą też występować inne 
zmienne, wyjaśniające wariancję w poziomie inkluzji społecznej, których ten model nie uwzględnił. Zawiera on jedynie zmienną $\varepsilon$ - „,resztę”, oznaczającą czynniki, których nie można wyjaśnić przez trzy główne zmienne.

\section{UWAGI KOŃCOWE}

Chociaż działania współdzielenia mają długą tradycję w rozwoju ludzkości, to ze względu na warunki rynku kapitalistycznego zasoby klientów muszą się stawać ich własnością prywatną, a nie wspólną. Jednakże proces globalizacji, przebiegający równolegle z gwałtownym rozwojem technologicznym, utorował droge interakcjom pomiędzy ludźmi, co z kolei stwarza możliwość ponownego podejmowania w życiu ekonomicznym działań z zakresu współdzielenia.

Szczególnie ważnym sektorem jest turystyka, jako że wymaga ciągłej interakcji między usługobiorcami a usługodawcami. Środki komunikacji umożliwiają relację opartą na zasadach ekonomii współdzielenia pomiędzy dostawcami chcącymi podzielić się swoją własnością a tymi, którzy jej pragną. Osoby, które angażują się we współdzielenie, zasadniczo przejawiają zachowania moralne związane z ochroną środowiska zgodne z filozofią I. Kanta. Podsumowując, należy podkreślić, że skoro żyjemy pośród natury, to powinniśmy dbać o zrównoważony rozwój środowiska, nawet poprzez drobne czynności dnia codziennego.

\section{BIBLIOGRAFIA}

Albinsson, P.A., Yasanthi Perera, B. (2012). Alternative marketplaces in the $21^{\text {st }}$ century: Building community through sharing events. Journal of Consumer Behaviour, 11 (4), 303-315.

Alexander, Z., Bakir, A. (2010). Understanding voluntourism: A glaserian grounded theory study. W: A.M. Benson (red.), Volunteer tourism. Theoretical frameworks and practical applications (s. 9-29). Oxford: Routledge.

Belk, R. (2010). Sharing. Journal of Consumer Research, 36 (5), 715-734.

Black, I.R., Cherrier, H. (2010). Anti-consumption as part of living a sustainable lifestyle: Daily practices, contextual motivations and subjective values. Journal of Consumer Behaviour, 9 (6), 437-453.

Botsman, R., Rogers, R. (2010). What's mine is yours. The rise of collaborative consumption. New York, NY: Harper Business.

Butcher, J. (2003). The moralization of tourism: Sun, sand... and saving the world? London: Routledge.
Dubois, E., Schor, J., Carfagna, L. (2014). Connected consumption: A sharing economy takes hold. Rotman Management, 50-55.

Frick, K., Hauser, M., Gürtler, D. (2013). Sharity: Die Zukunft des Teilens, GDI-Studie. Rüschlikon, Zürich: Gottlieb Duttweiler Institute.

Fullagar, S., Markwell, K., Wilson, E. (red.) (2012). Slow tourism: Experiences and mobilities. Bristol, UK: Channel View Publications.

Glind, P.B. van de (2013). The consumer potential of collaborative consumption: Identifying the motives of Dutch collaborative consumers $\mathcal{E}$ measuring the consumer potential of collaborative consumption within the municipality of Amsterdam. Master's thesis. Utrecht: Utrecht University, Faculty of Geosciences Theses.

Haenfler, R., Johnson, B., Jones, E. (2012). Lifestyle movements: Exploring the intersection of lifestyle and social movements. Social Movement Studies, 11 (1), 1-20.

Hamari, J., Sjöklint, M., Ukkonen, A. (2015). The sharing economy: Why people participate in collaborative consumption. Journal of the Association for Information Science and Technology, 67 (9), 2047-2059.

Heinrichs, H. (2013). Sharing economy: A potential new pathway to sustainability. Gaia, 22 (4), 228-231.

Jänicke, M., Kunig, P., Stitzel, M. (1999). Study and Workbook Environmental policy: Policy, law and management of environmental protection in state and enterprise. Bonn, Germany: Dietz.

Kant, I. (2002). Groundwork for the metaphysics of morals. Opracował i przetłumaczył Allen W. Wood. Binghamton, New York: Vail-Ballou Press.

Lyons, K., Hanley, J., Wearing, S., Neil, J. (2012). Gap year volunteer tourism: Myths of global citizenship? Annals of Tourism Research, 39 (1), 361-378.

McNeill, J.R. (2003). Blue planet: The history of environment in $20^{\text {th }} \mathrm{cen}$ tury. Frankfur, Germany: Campus Verlag.

Molz, J.G. (2013). Social networking technologies and the moral economy of alternative tourism: The case of Couchsurfing.org. Annals of Tourism Research, 43, 210-230.

Owyang, J., Samuel, A., Grenville, A. (2014). Sharing is the new buying: How to win in the collaborative economy. Vancouver, BC: Vision Critical and Crowd Companies.

Pink, S. (2008). Re-thinking contemporary activism: From community to emplaced sociality. Ethnos, 73 (2), 163-188.

Rentmeester, C. (2010). A Kantian look at climate change. Essays in Philosophy, 11 (1), 76-86.

Sayer, A. (2004). Moral economy. Lancaster: Department of Sociology, Lancaster University.

Schiel, F. (2015). The phenomenon of the sharing economy in Germany: Consumer motivations for participating in collaborative consumption schemes. Praca magisterska. Enschede: University of Twente.

Scholl, G., Schulz, L., Süßbauer, E., Otto, S. (2010). Benefit instead of possessing perspectives for resource-efficient consumption through innovative services. Resource efficiency paper, 12.4. Berlin, Germany: Wuppertal-Institut.

Schönfeld, M. (2008). The green Kant: Environmental dynamics and sustainable policies. W: L.P. Pojman, P. Pojman (red.), Environmental Ethics: Readings in theory and application (s. 49-60). Belmonth: Thomson-Wadsworth.

Schor, J. (2016). Debating the sharing economy. Journal of Self-Governance and Management Economics, 4 (3), 7-22. 